\title{
ЩОДЕННИЙ ДИСТАНЦІЙНИЙ ТЕСТОВИЙ КОНТРОЛЬ ЗНАНЬ ЯК ІНСТРУМЕНТ ФОРМУВАННЯ МЕДИКО-ПРАВОВОЇ ОСВІТИ СТУДЕНТІВ-МЕДИКІВ
}

\author{
В. П. Марценюк, І. О. Рогальський \\ ДВНЗ «Тернопільський державний медичний університет імені І. Я. Горбачевського \\ МОЗ України» \\ У роботі представлено небезпеку корупції в галузі медичної освіти на тлі загальнодержавної проблеми. Тому \\ вкрай актуальним постає формування медико-правової освіти, починаючи на додипломному етапі підготовки \\ фахівців-медиків при оцінюванні рівня теоретичних знань. Як інструмент обрано систему щоденного дистанційно- \\ го тестового контролю знань студентів-медиків, покликану об'єктивізувати процес оцінювання в медичній освіті. \\ Система дозволяє викладачам засобами Інтернет-технологій самостійно готувати щоденний тестовий контроль, а \\ студентам-медикам відкинути сумніви в об'єктивності їх оцінювання і закласти підвалини медико-правової освіти.
}

Ключові слова: медична освіта, корупція, оцінювання знань, Інтернет-технології.

\section{ЕЖЕДНЕВНЫЙ ДИСТАНЦИОННЫЙ ТЕСТОВЫЙ КОНТРОЛЬ ЗНАНИЙ КАК ИНСТРУМЕНТ ФОРМИРОВАНИЯ МЕДИКО-ПРАВОВОГО ОБРАЗОВАНИЯ СТУДЕНТОВ-МЕДИКОВ}

\author{
В. П. Марценюк, И. О. Рогальський \\ ГВУЗ «Тернопольский государственный медицинский университет \\ имени И. Я. Горбачевского МОЗ Украины»
}

\begin{abstract}
В работе представлена опасность коррупции в области медицинского образования на фоне общегосударственной проблемы. Поэтому крайне актуальным становится фрормирование медико-правового образования, начиная на додипломном этапе подготовки специалистов-медиков при оценке уровня теоретических знаний. Как инструмент выбрана система ежедневного дистанционного тестового контроля знаний студентов-медиков, призванная объективизировать процесс оцениванивания в медицинском образовании. Система позволяет преподавателям средствами Интернет-технологий самостоятельно готовить ежедневный тестовый контроль, а студентам-медикам отбросить сомнения в объективности их оценивания и заложить основы медико-правового образования.
\end{abstract}

Ключевые слова: медицинское образование, коррупция, оценивание знаний, Интернет-технологии.

\section{DAILY REMOTE TEST CONTROL KNOWLEDGE AS A TOOL FOR MEDICAL AND LEGAL EDUCATION OF MEDICAL STUDENTS}

\section{P. Martsenyuk, I. O. Rogalskyi}

SHEI «Ternopil State Medical University by I. Ya. Horbachevsky of MPH of Ukraine»

\begin{abstract}
The article presents the danger of corruption in medical education as a national problem. Therefore, the formation of medical legal insight is very important since the undergraduate stage of training health professionals in the assessment of theoretical knowledge. The system of daily remote control testing medical students' knowledge was chosen as a tool, which was designed to objectify the evaluation in medical education. The system allows teachers to prepare daily test control using internet technologies, and promote medical students to reject any doubts about the objectivity of the evaluation and to form the basis of medical legal education.
\end{abstract}

Key words: medical education, corruption, assessment, online technology.

Вступ. Корупція, як одне 3 найзгубніших явищ для будь-якої держави, стала для України на початку третього тисячоліття основною перешкодою для політичного, економічного і духовного розвитку, пе- ретворилася на реальну загрозу для національної безпеки країни, головне гальмо на шляху будь-яких перетворень. Ставши фактично одним 3 елементів функціонування держави, невід'ємною складовою іiі 
взаємин з громадянами, корупція породила жахливі диспропорції не тільки в системі управління і функціонування державних інститутів, але і призвела до серйозних зрушень в свідомості громадян, які все більше i більше втрачають довіру до влади і віру в справедливість [I, 2].

Дані кримінальної статистики, соціологічні опитування і оцінки експертів показують, що корупція вразила практично всі сфери нашого життя - від державної служби і правоохоронних органів до охорони здоров'я та освіти. Рівень і масштаби корупції, що існує в країні, стримують економічний розвиток України, негативно відображаються на інвестиційному кліматі, зменшують міжнародну зацікавленість у співпраці з нашою країною [I, 2].

Ураження корупцією владних структур неминуче призводить до зниження ролі держави як регулятора економічних і соціальних процесів, стимулює паразитування незначної частини суспільства на проблемах і труднощах більшості, переводить нормальну систему взаємин між людьми в тіньову, часто кримінальну сферу. Особливо небезпечна корупція в правоохоронних органах, спецслужбах, прокуратурі, судовій системі, оскільки вона підриває віру населення в здатність держави захистити права і свободи своїх громадян [I].

Протидія корупції стала в даний час найважливішим стратегічним завданням діяльності Української держави і її громадянського суспільства.

Метою даної роботи є представити основні шляхи і напрями розв'язання даної проблеми в сфері медичної освіти. В якості інструменту формування медико-правової освіти запропоноване впровадження щоденного дистанційного тестового контролю знань студентів.

Зловживання в охороні здоров'я та освіті як зони побутової корупції. Громадяни України реально відчувають вплив корупції в ході своєї безпосередньої взаємодії з представниками органів державної влади і місцевого самоврядування, коли часто будь-яке питання вирішується тільки після надання «хабара», а згідно нового КПК - одержання неправомірної вигоди, відповідному чиновникові в найрізноманітніших формах. Розмах корупції на побутовому рівні настільки значний, що в масовій свідомості вкорінилася думка, що без «стимулювання» того або іншого службовця або посадовця практично неможливо вирішити жодної життєвої проблеми.

Відсутність чіткої регламентації надання послуг в різних сферах діяльності, зокрема при вирішенні конкретних питань, з приводу яких громадяни звертаються безпосередньо в органи влади, приводить до величезних зловживань. Саме на цьому побутовому рівні формується негативне ставлення людей до влади в цілому, створюється уявлення в масовій свідомості про її тотальну продажність і корумпованість. В результаті у великої частини населення країни поступово складається стереотип корупції, як етично прийнятної форми вирішення проблем, розмивається розуміння суспільної небезпеки цього явища, знижується поріг моральної терпимості населення до «хабарництва» і поборів [2].

Не дивлячись на те, що масштаби побутової корупції не роблять істотного впливу на економіку країни в цілому, цей її вигляд серйозно деморалізує простих громадян, розкладає чиновників, робить корупцію повсякденною, буденною, по суті, загальноприйнятим і навіть незасуджуваним суспільством явищем.

Найхворобливіше громадянами сприймається отримання неправомірної вигоди, здирство і інші зловживання корупційного характеру у сфері охорони здоров'я, тому що в масовій свідомості професія лікаря асоціюється з безкорисливим і самовідданим служінням людям, а здоров'я є фундаментальним людським благом, без якого багато інших цінностей втрачають свій сенс. При цьому йдеться вже не стільки про дрібні винагороди у вигляді підношень лікарям за лікування, скільки про ті, що почастішали останніми роками, небезпечні прояви: отримання лікарями бонусів від фірм-виробників за рекомендацію хворим ліків конкретних фірм, зрозуміло, не найдешевших і часто не найефективніших. Відбувається закупівля дорогих, але менш ефективних ліків.

Стаття 49 Конституції України визначає право на охорону здоров'я. Вона проголошує, що кожен має право на охорону здоров'я, медичну допомогу та медичне страхування. Тобто в Україні кожна людина володіє проголошеними конституційними правами і свободами в діючій системі охорони здоров'я та медичного забезпечення. При цьому реалізація права на охорону здоров'я забезпечується державним фінансуваням відповідних соціально-економічих, медико-санітарних та оздоровчо-профілактичних програм. Ця правова норма засвідчує відповідальнісь держави за реалізацію громадянами права на охорону здоров'я. Постійне та зрозуміле зростання вартості медичного обслуговування робить проблематичним надання безоплатної кваліфікованої медичної допомоги, що породжує ряд зловживань та корупційних діянь у цій сфері.

Звідси - зниження довіри громадян до лікарів i масове поширення різних видів самолікування і звернення до шахраїв. 
В галузі освіти, як і раніше, головним проявом корупції є отримання неправомірної вигоди за вступ у вищі навчальні заклади, масштаби яких досягають розмірів, недоступних навіть громадянам із середніми доходами. 3 введенням в дію системи сертифікатів по складанню державних тестових іспитів $є$ важливим недопущення фактів отримання неправомірної винагороди за надання високих балів.

Проблему становить належне об'єктивне оцінювання знань, які студенти набувають в ході навчально-педагогічного процесу, i, як результат, невідповідність рівня теоретичних знань і клінічної компетентності (коли мова йде про студентів-медиків) тим, що засвідчені в дипломі [3]. Нерідкими є факти навмисного втручання в процес оцінювання зі сторони професорсько-викладацького складу. Така можливість з'являється тоді, коли застосовуються необ'єктивні, морально застарілі методики оцінювання - такі як усна співбесіда 3 викладачем, письмова відповідь у вигляді ессе в довільній формі і ін. Тому в даній роботі запропонована до використання нова система дистанційного щоденного контролю знань студентів-медиків, яка грунтується на інформаційних та тестових технологіях.

Система щоденного дистанційного контролю знань студентів, яка пропонується і вже використовується у Тернопільському державному медичному університеті ім. І. Я. Горбачевського, реалізована за допомогою програмного середовища Моойе. Це програмне середовище належить до класу прикладних програм, відомих під назвами - системи дистанційної освіти, мережеві навчальні системи, інформаційні системи електронного навчання і ін. їх спільною особливістю є надання можливостей:

- кожному студенту та викладачу переглядати навчально-методичні матеріали;

- взаємодіяти між учасниками навчального процесу;

- оцінювати навчальний рівень джерел інформації та мати до них доступ в будь-який момент часу.

Такі системи існують на багатьох рівнях всередині навчальних підрозділів і поза ними:

- комп'ютерні мережі навчальних аудиторій;

- комп'ютерні мережі кафедр;

- комп'ютерні мережі факультетів та інститутів;

- електронні бібліотеки;

- електронні навчальні ресурси (комп'ютерні симулятори та манекени) i iн.

При цьому досягається висока взаємодія між:

- викладачами;

- студентами;

- широким колом осіб в медіа-центрах, бібліотеках, інших навчальних закладах, науково-дослідних лабораторіях, лікувальних закладах, будь-яких інших місцях, де збирається навчально-наукова інформація, створюються знання та зберігаються навчальні ресурси.

Технічними особливостями таких програмних систем є наступне:

- програми працюють на зразок поштових серверів (Yahoo);

- робота студента або викладача нагадує роботу iз власною електронною поштовою скринькою;

- створюються папки (Inbox), в яких зберігаються методичні матеріали, присвячені різним навчальним дисциплінам;

- $є$ можливість вести інтерактивне спілкування (чат) з викладачами згідно із розкладом;

- пересилати комп'ютерне відео та презентації;

- здійснювати оцінювання знань студентів.

Саме остання можливість таких систем використана в Тернопільському державному медичному університеті для організації та проведення щоденного дистанційного тестового контролю знань студентів.

Робота викладача в системі Moodle розпочинається із створення сайту дисципліни. Це робота адміністратора системи. Він вводить назву дисципліни, задає кількість занять, підключає викладачів та студентів даної навчальної дисципліни згідно логінів та паролів.

Статистичний аналіз ефективності використання системи щоденного дистанційного тестового контролю знань 3 метою формування медико-правової освіти студентів-медиків. Для оцінки рівня медико-правової освіти студентів-медиків в 2007/08 та 20I2/I3 навчальних роках в Тернопільському державному медичному університеті проведено експериментальні курси з медичного права для 259 студентів-медиків. На першому етапі було встановлено ступінь Інтернет-обізнаності. Більшість студентів добре володіла Інтернет-технологіями (рис. I).

Середній вік студентів був 21 рік, кількість осіб жіночої статі складала 52,3 \%. На другому етапі було проведене рандомізоване дослідження щодо зіставлення ефективності використання в навчальному процесі Веб-порталу навчально-методичних матеріалів. Студенти були поділені на дві групи: дослідну (142 студенти 20I2/I3 н.р.) та контрольну (117 студентів 2007/08 н.р.).

Студенти контрольної групи опановували предмет в звичайному форматі, а дослідної - той самий предмет, але використовуючи систему щоденного дистанційного тестового контролю знань 3 авторизованим доступом. 


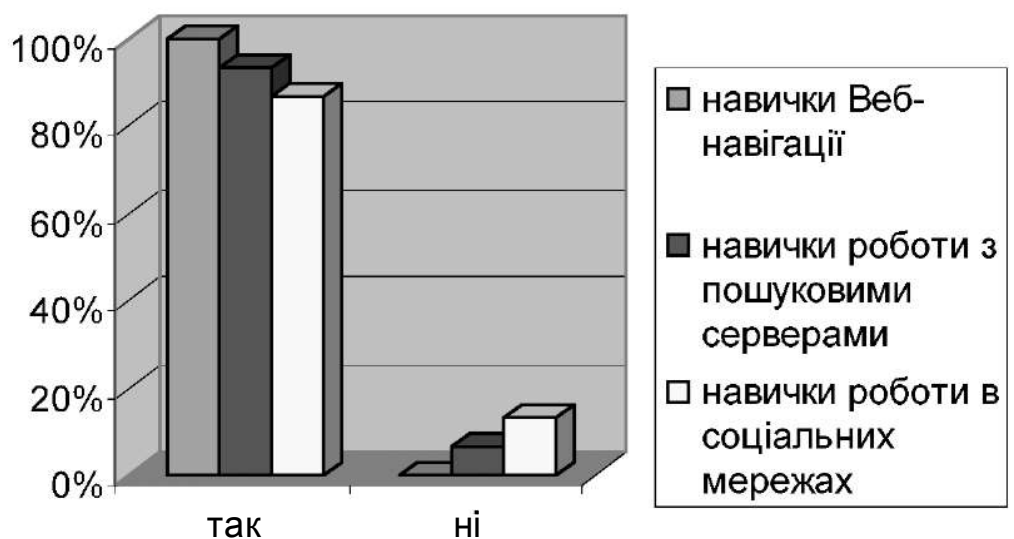

Puc.1. Володіння Інтернет-технологіями.

3 метою перевірки ефективності системи щоденного дистанційного тестового контролю знань для опанування теоретичних знань було використано мо- дульний контроль (на основі середніх оцінок практичних та семінарських занять). Отримані результати наведені в таблиці I.

Таблиця І. Зіставлення позитивних відповідей по групах студентів

\begin{tabular}{|c|c|c|c|c|c|c|c|c|}
\hline \multirow{3}{*}{ Вид завдання } & \multirow{3}{*}{$\begin{array}{c}\text { Кількість } \\
\text { завдань }\end{array}$} & \multicolumn{6}{|c|}{ Позитивні вщповіді по групах студентів } & \multirow{3}{*}{$\mathrm{P}$} \\
\hline & & \multicolumn{3}{|c|}{ контрольна(п=117) } & \multicolumn{3}{|c|}{ основна $(\Pi=142)$} & \\
\hline & & абс. & $\%$ & $+\mathrm{T} \%$ & абс. & $\%$ & $+\mathrm{T} \%$ & \\
\hline $\begin{array}{l}3 \text { відкритими короткими } \\
\text { відповідями }\end{array}$ & 32 & 2985 & 79,7 & 0,7 & 2576 & 56,7 & 0,7 & $<0,05$ \\
\hline $\begin{array}{l}3 \text { графічними } \\
\text { зображеннями }\end{array}$ & 12 & 931 & 66,3 & 1,3 & 650 & 38,1 & 1,2 & $<0,05$ \\
\hline $\begin{array}{l}\text { У ветляді ситуаційних } \\
\text { задач }\end{array}$ & 4 & 198 & 42,3 & 2,3 & 152 & 26,8 & 1,9 & $<0,05$ \\
\hline
\end{tabular}

Після завершення вивчення предмета також було здійснене спеціальне анонімне анкетування, метою якого була оцінка ефективності використання системи щоденного дистанційного тестового контролю на основі відповідей студентів. Анкети включали в себе питання про
Інгернет-обізнаність студентів, а також ступінь ефективності навчального процесу за рядом показників.

Нижче наведено результати відповідей на основі запитання щодо загальної характеристики навчального курсу (табл. 2).

Таблиця 2. Зіставлення результатів відповідей на основі запитання щодо загальної характеристики навчального предмета

\begin{tabular}{|c|c|c|c|c|c|c|c|}
\hline \multirow{3}{*}{ Питання анкети } & \multicolumn{6}{|c|}{ Група студентів } & \multirow{3}{*}{$\mathrm{P}$} \\
\hline & \multicolumn{3}{|c|}{ контрольна (п=117) } & \multicolumn{3}{|c|}{ основна $(\Pi=142)$} & \\
\hline & абс. & $\%$ & $+\mathrm{T} \%$ & абс. & $\%$ & $+\mathrm{T} \%$ & \\
\hline 1 & 2 & 3 & 4 & 5 & 6 & 7 & 8 \\
\hline $\begin{array}{l}\text { Чи був громіздким матеріал } 3 \\
\text { даного предмета }\end{array}$ & 82 & 70,1 & 4,2 & 91 & 64,1 & 4,0 & $>0,05$ \\
\hline $\begin{array}{l}\text { Чи отримали Ви достатні } \\
\text { знання } 3 \text { даного предмета }\end{array}$ & 71 & 60,7 & 4,5 & 112 & 78,9 & 3,4 & $<0,05$ \\
\hline $\begin{array}{l}\text { Чи отримали Ви ефективне } \\
\text { практичне застосування даної } \\
\text { дисципліни }\end{array}$ & 95 & 81,2 & 3,6 & 124 & 87,3 & 2,8 & $>0,05$ \\
\hline $\begin{array}{l}\text { Чи достатньо сучасною була } \\
\text { викладена інформація в } \\
\text { навчально-методичних } \\
\text { матеріалах }\end{array}$ & 56 & 47,9 & 4,6 & 109 & 76,8 & 3,5 & $<0,05$ \\
\hline
\end{tabular}


Продовження табл. 2

\begin{tabular}{|c|c|c|c|c|c|c|c|}
\hline 1 & 2 & 3 & 4 & 5 & 6 & 7 & 8 \\
\hline $\begin{array}{l}\text { Чи повноцінно } \\
\text { супроводжувався виклад } \\
\text { предмета практичним } \\
\text { унаочненням }\end{array}$ & 63 & 53,9 & 4,6 & 115 & 81,0 & 3,3 & $<0,05$ \\
\hline $\begin{array}{l}\text { Чи оперативним був у Вас } \\
\text { доступ до сучасних } \\
\text { інформаційних джерел } 3 \\
\text { даного предмета }\end{array}$ & 83 & 70,9 & 4,2 & 121 & 85,2 & 3,0 & $<0,05$ \\
\hline
\end{tabular}

Як можна бачити 3 таблиці 2, для значної кількості студентів обох груп матеріал предмета був громіздким. Відповідний довірчий інтервал складав $(70, \mathrm{I} \pm 4,2) \%$ у контрольній групі та $(64, \mathrm{I} \pm 4,0) \%$ в основній групі.

Підкреслимо, що статистично достовірних розходжень між дослідною та контрольною групами тут не виявлено ( $>>0,05)$. Це ж стосується, на жаль, i ефективності практичного застосування знань. Хоча спостерігається певне кількісне зростання у ствердних відповідях про набуті якісні знання та навички, таке збільшення не є статистично достовірним.

За усіма запитаннями отримано достовірні зміни в сторону покращення при використанні Веб-порталу навчально-методичних матеріалів. Особливо такі зміни є значущими, коли мова йде про сучасність наданого матеріалу при опануванні дисципліни, про застосування усіх необхідних знань на практиці, про доступ до сучасних інформаційних джерел з даного предмета.

Аналіз результатів ефективності використання системи щоденного дистанційного тестового контролю знань для формування медико-правової освіти на додипломному етапі свідчить про його суттєве зна-

\section{Література}

1. Спільні перший та другий раунди оцінювання. Оціночний звіт по Україні / Генеральний директорат з прав людини та юридичних питань, Директорат моніторингу. м. Страсбург, 21 березня 2007 p. - www.coe.int/greco.

2. Звіт про дотримання прав людини - 2006 рік / Оприлюднено Бюро з питань демократії, прав людини і праці Дер- чення для організації навчального процесу на сучасному етапі.

Висновки. Ефективно протидіяти корупції можна тільки системними засобами, витісняючи корупційні процеси з політичного і суспільного життя, економіки і сфери управління. Комплексні заходи протидії повинні здійснюватися по всіх напрямах з урахуванням встановлених пріоритетів - правових, організаційних, управлінських, виховних і інших.

Такі заходи обов'язково повинні врахувати найвразливіші для громадян прояви корупції - так звану побутову корупцію. У роботі розглянуто галузь медичної освіти, наслідки ураження якої корупцією є одними 3 найбільш руйнівних для суспільства - надання неякісної та неефективної медичної допомоги.

Тому тут запропоновано інформаційну систему щоденного дистанційного тестового контролю знань студентів-медиків, покликану, зокрема, об'єктивізувати процес оцінювання в медичній освіті, який традиційно вважається одним із найбільш корумпованих.

Система дозволяє викладачам засобами Інтернеттехнологій самостійно готувати щоденний тестовий контроль, а студентам-медикам відкинути сумніви в об'єктивності їх оцінювання.

жавного департаменту США 6 березня 2007 року - http:// web.usembassy.kiev.ua.

3. Банчук М. В. Політика комп'ютеризованого тестового іспиту в контексті демократизації медичної освіти. Свропейський та український досвід / М. В. Банчук // Медична інформатика та інженерія. - 2008. - № I. - С. 30-39. 